\title{
COUNTRYMUSIIKIN KÄYTTÖ ALKUPERÄISMUSIIKISSA ELOKUVASSA NUORI BONNER
}

Tarkastelen katsauksessani countrymusiikin käyttöä ja sen luomia merkityksiä yhdysvaltalaisessa draamaelokuvassa Nuori Bonner (Junior Bonner, ohjannut Sam Peckinpah 1972). Elokuva kertoo rodeotähti J. R. Bonnerista (Steve McQueen), joka palaa vuosien jälkeen kotikaupunkiinsa Arizonan osavaltion Prescottiin osallistuakseen vuosittaisiin rodeokilpailuihin. Hänen tavoitteenaan on myös yhdistää erilleen kasvanut perheensä ja voittaa rahat isälleen Acelle (Robert Preston), jotta tämä voisi pitää Australiassa lammasfarmia. Elokuvan countrytyylisen alkuperäismusiikin on säveltänyt amerikkalainen Jerry Fielding.

Kiinnitän analyysissäni erityistä huomiota musiikin ja kuvan yhdessä luomiin merkityksiin: miten countrymusiikkia käytetään elokuvassa? Mitä merkityksiä countrylla halutaan rakentaa? Tarkastelen myös miten musiikki ilmentää lounaisosien miljöötä ja cowboy-identiteettiä? Lisäksi sovellan analyysissäni kontekstuaalista lähilukua, keskittymällä erilaisiin Nuori Bonner -elokuvassa ilmeneviin elokuvamusiikillisiin topoksiin, kuten countrytyyliin ja sille tyypilliseen instrumentaatioon, jotka ovat merkityksenannon kannalta tärkeitä.

Countrylla (myös country and western) tarkoitetaan Yhdysvaltojen Etelässä ja Länsiosissa 1900-luvun alussa syntynyttä populaarimusiikin genreä, joka muodostui Appalakkien vuoriston kelttiläisistä vaikutteista. Etelävaltiot ja varsinkin Appalakkien vuoristo oli 1900-luvulle asti eristäytynyt yhteisö, missä viktoriaaniset ja vanhat englantilaiset, skottilaiset ja irlantilaiset kansanlaulut säilyivät miltei muuttumattomina 1900-luvun alkuun. Bill C. Malonen mukaan ennen Villin lännen teemoja soveltavaa western-musiikin nousua 1930-luvulla "vanhan ajan musiikki" (engl. old time music) jakautui kahteen tyyliin: yksilölliseen lauluun, ei-perinteiseen instrumentaatioon sekä populaarimusiikin ja afrikkalais-amerikkalaisen musiikin vaikutteiseen countryyn ja perinteisiin lauluihin ja nasaaleihin lähiharmonioihin perustuvaan vuoristolaismusiikkiin (engl. mountain music). (Malone 1975, 33-34, 62.)

\section{Etelävaltioiden audiovisuaaliset stereotypiat ja topokset}

Stereotyypittely on yksi keskeisiä merkityksenantoprosesseja Etelävaltioiden, lännen ja valkoisen identiteetin audiovisuaalisessa ilmentämisessä. Stuart Hallin mukaan prosessissa kuvataan tiettyä asiaa, ryhmää tai henkilöä helposti omaksuttavilla, pelkistetyillä ja yleisesti tunnetuilla essentialistisilla piirteillä $(2002,122,190-191)$.

Populaarikulttuuri on käyttänyt stereotyypittelyä Yhdysvaltojen Etelän ja sen asukkaiden representaatiossa. Esimerkiksi Etelän maalaismiljöötä ja sen stereo- 
tyyppisiä henkilöhahmoja soveltava hiksploitaatio-elokuvagenre (engl. hicksploitation) tulee englanninkielen maalaista sanasta "hick" ("maalaistollo", "juntti") ja sensaatiomaisille aiheilla mässäilevästä exploitation-genrestä (suom. eksploitaatio, hyväksikäyttö, hyödyntäminen). Tällä eksploitaation alagenrellä tarkoitetaan sananmukaisesti maalaismiljöön ja sen asukkaiden hyväksikäyttämistä. Etelän stereotyyppiset henkilöhahmot esitetään usein joko hyväsydämisinä mutta mieleltään yksinkertaisena väestönä tai verenhimoisina takametsien paholaisina, jotka suhtautuvat vihamielisesti Pohjoisen asukkaisiin. Esimerkiksi Herschell Gordon Lewisin ohjaamassa varhaisessa splatter-elokuvassa Two Thousand Maniacs (USA 1964) Etelän pikkukaupunki Pleasant Valley ohjaa pahaa aavistamattomat Pohjoisen nuoret kaupunkiinsa viettämään Amerikan sisällissodan 100-vuotisjuhlaa kostaakseen "kunniavierailleen" Unionin sotilaiden vuosisadan takaiset julmuudet.

Maalaisväestön stereotyyppisessä representaatiossa countrymusiikilla on myös keskeinen rooli, koska se assosioidaan Yhdysvaltojen valkoiseen väestöön ja identiteettiin. Elokuva Two Thousand Maniacs alkaa tomuiselta hiekkatieltä, kun banjo näppäilee Etelävaltioiden kansallislaulu "Dixien" (1861) ensimmäiset sävelet. Samassa The Pleasant Valley Boysin teemalaulu "South's Gonna Rise Again" käynnistyy. Säkeistön puhutut sanat kertovat sisällissodan tapahtumista satiirisesti, mikä viittaa elokuvan teemaan. Countrylle ja bluegrass-musiikille tyypillisessä kvinttiharmoniassa lauletussa kertosäkeessä hihkutaan falsetissa "yeehaw", mikä viittaa Konfederaation sotilaiden taisteluhuutoon (engl. rebel yell), jonka perään lauletaan: "Etelä nousee uudestaan". Konfederaation kansallislaulu on yksi tunnistettavimpia Etelään yhdistettäviä melodioita, mikä ilmentää Etelän stereotyyppistä vaikutelmaa. Kappaleen "Rebel Yell" bluegrass-tyyli puolestaan viittaa erityisesti maalaisväestön valkoiseen identiteettiin.

\section{Elokuvamusiikin topokset}

Elokuvamusiikki soveltaa paljon vakiintuneita kliseisiä aiheita ja merkkejä, jotka esittävät keskeistä roolia niin tarinankerronnassa kuin myös hahmojen ja miljöön kuvaamisessa. Musiikkisemiotiikasta lainatussa toposteoriassa topoksella tarkoitetaan melodis-rytmistä aihetta, jolla on tietty semanttinen merkitys (Hautsalo 2010, 88). Musiikintutkimukseen teoriaa sovelsi ensimmäisen kerran musiikkisemiootikko Leonard Ratner (1980), tarkastellessaan wieniläisklassismin vakiintuneita aiheita. Raymond Monelle taas jakaa topokset tiettyn tyyliin viittaaviin teoksien sisäisiin tyylitopoksiin ja useimmiten sävellyksen perustana toimiviin tyyppitopoksiin. Tyylitopoksia voivat olla esimerkiksi teoksessa kuultava militaarinen torvikutsu, kun taas esimerkiksi ranskalaiseen bourrée-muotitanssiin tai katrilliin perustuva teos on tyyppitopos. (Monelle 2006.)

Elokuvamusiikin topoksia on tutkinut muun muassa elokuvamusiikintutkija Susanna Välimäki tarkastellessaan sitä, miten sota soi (Välimäki 2008). Välimäen mukaan topokset ovat "musiikin semanttisen ilmaisun vakiosanastoja, tunnistettavia musiikillisia kommunikaatiokaavoja, tyyleihin, lajeihin ja muihin sovittuihin merkityksiin viittaavia merkkejä" $(2008,42)$. Jopa ilman katsomista katsoja tunnistaa toposten avulla, mitä elokuvassa tapahtuu. Useimmiten myös miljöö tulee selväksi, koska tietyt vakiintuneet merkit assosioituvat tiettyyn kulttuuriin ja alueeseen. Esimerkiksi countrymusiikista ja erilaisista tyyliviitteistä, kuten huuliharpusta, steel-kitarasta, resonaattorikitarasta tai viulusta, tunnistamme elokuvan sijoittuvan esimerkiksi Teksasiin tai Yhdysvaltojen Lounaisosiin. 


\section{Countrymusiikin käyttö elokuvissa}

Country itsessään on luokiteltavissa tyyppitopokseksi, koska sen harmoniaa, rytmikkaa ja instrumentaatiota on käytetty useissa elokuvissa. Yksi keskeisiä konventioita on muun muassa takamaiden kaahailujakso, jossa nopea banjonäppäily ilmentää vauhdin hurmaa. Yksi tunnetuimpia kohtauksia on pakomontaasi tosielämän 1930-luvun laman ajan pankkirosvoista kertovassa elokuvassa Bonnie ja Clyde (Bonnie and Clyde, USA, ohjannut Arthur Penn 1967). Kiihkeää pakoa hiekkateillä rytmittää salamannopealla banjonäppäilyllä alkava Lester Flattsin ja Earl Scruggsin muodostaman bluegrass-duon instrumentaalikappale "Foggy Mountain Breakdown", joka käynnistyy, kun pikkukaupungin pankin hälytyssireeni alkaa soida ja rosvot ajavat tiehensä poliisit kannoillaan. Pakojaksoa leikataan rinnakkain silminnäkijöiden haastatteluihin, joissa musiikkia ei kuulla, mikä osoittaa jakson sijoittuvan eri aikaan ja tilaan.

Takaa-ajossa poliisiautot päätyvät kyljelleen rosvojen kaahatessa osavaltion rajan yli, mistä myöhemmin tuli salapolttajista kertovien 1970-luvun hiksploitaatio-elokuvien, kuten Kumi sulaa asfaltilla (Bad Georgia Road, USA, ohj. John C. Broderick, 1977) tai Valkea Salama (White Lightning, ohj. John Sargent, 1973) keskeisiä konventioita. Lisäksi konventiota on parodioitu Simpsonien jaksossa "Papan ihmelääke" ("Granpa vs. the Sexual Inadequacy", USA, Fox 1994), jossa maalaiset aloittavat ihmelääkettä kaupustelevien Homer Simpsonin ja hänen isänsä Abrahamin takaa-ajon, kun Abraham laittaa päälle"takaa-ajomusiikin", "Foggy Mountain Breakdownin". Vilpistä suuttuneet maalaiset kääntyvät avolava-autollaan takaisin, kun Abe sammuttaa radion. Tämä parodia osoittaa takaa-ajo-konvention merkitystä populaarikulttuurissa.

Countrymusiikin instrumentaatio toimii orkestraalisen alkuperäismusiikin sisäisenä tyylitopoksena myös John Williamsin säveltämässä, William Faulknerin romaaniin perustustavan elokuvan Veijarit (The Reivers, USA, ohj. Mark Ridell, 1969) teemalaulussa, jossa sinfonisen kudoksen säestämänä huuliharppu soittaa kansanomaista melodiaa. Tyylitopoksena toimiva huuliharppu yhdessä Etelävaltioiden stereotyyppisen kuvaston, kuten puuvillapeltojen ja aavojen jokitörmien, kanssa vahvistaa kuvan merkityksiä luomalla kuvallisen materiaalin ohella vaikutelmaa elokuvan 1900-luvun alkuvuosien Mississippin syvän Etelän miljööstä. Lisäksi erilaisia valmiita countrykappaleita voidaan pitää topoksina, jotka liittyvät kiinteästi muun muassa hiksploitaatio-genreen. Kuuluisimpia teemalauluja lienee Reedin Konna ja Koukku -elokuvaa (Smokey and the Bandit, USA, ohj. Hal Needman, 1977) varten säveltämä "Eastbound and Down" (1977) sekä Jenningsin Duken salapolttajaserkuksista kertovan sarjan Dukes of Hazzard (CBS 1979-1985) alkuteksteissä kuultava "Theme from Dukes of Hazzard" (1980).

\section{Countrymusiikki elokuvan Nuori Bonner musiikkiraidalla}

Nuori Bonner sisältää paljon countrymusiikkia, mikä ilmentää Arizonan lounaisosien miljöötä ja amerikkalaista cowboy-identiteettiä. Country on ns. cowboy-tyylitopos, mikä assosioituu Etelävaltioiden lounaisiin osavaltioihin, missä western-musiikki syntyi 1930-luvulla. Nuori Bonner sisältää niin Jerry Fieldingin säveltämää countrytyylistä alkuperäismusikkia kuin myös laulaja-lauluntekijä Rod Hartin kappaleet "Rodeo Man" ja "Arizona Morning". Kappale "Rodeo Man" kuullaan sekä baarikohtauksessa että lopputeksteissä, joissa seurataan ilmakuvana iltahämärässä loputtomalta vaikuttavaa aavikkotietä ajavaa J. R. Bonneria. Vähitellen horisonttiin katoava, autonsa perässä hevostaan vetävä cowboy vaikuttaa olevan moderni versio lännenelokuvien lopputeksteistä, joissa päähenkilö ratsastaa auringonlaskuun suuria 


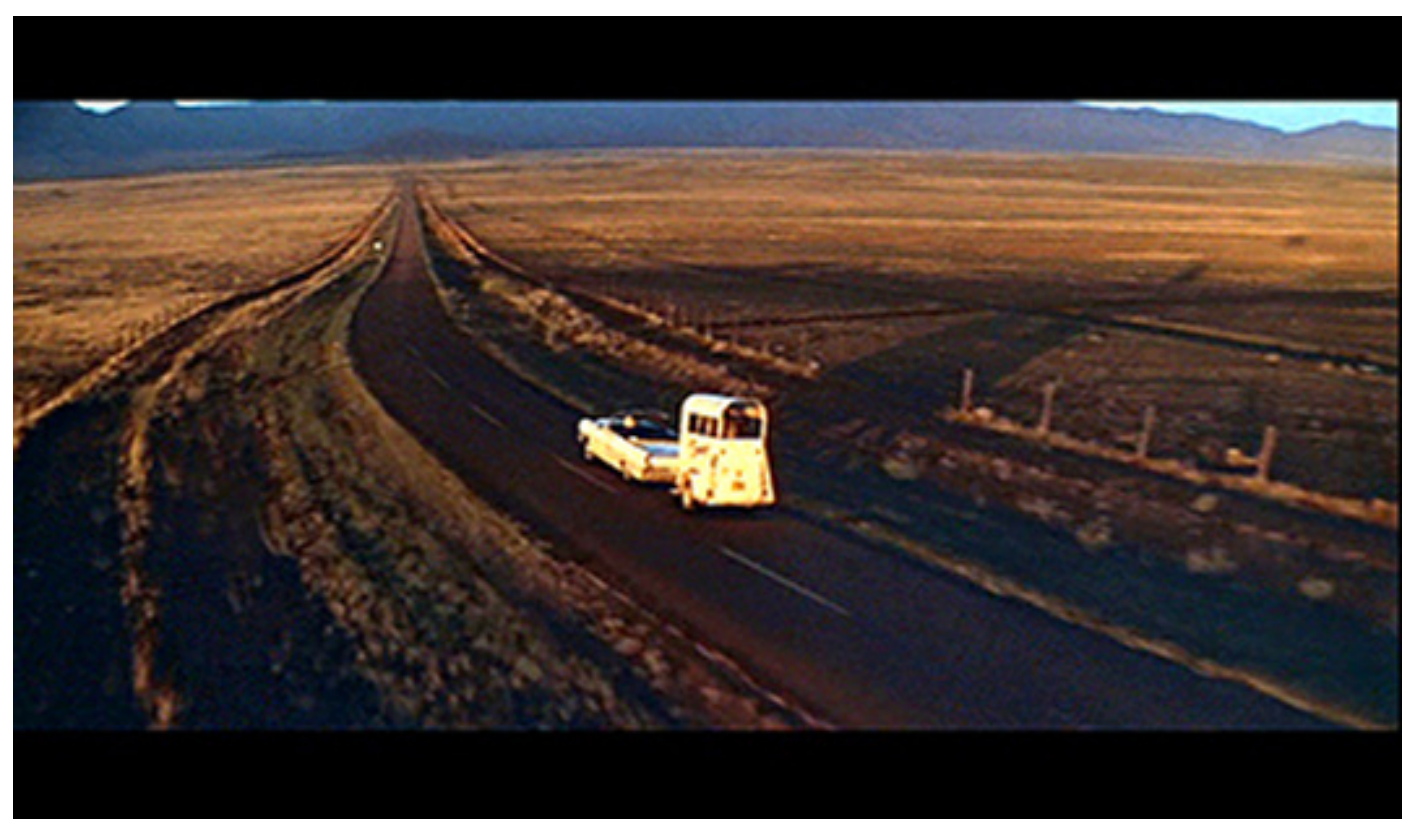

Yksinäinen cowboy "ratsastaa" auringonlaskuun Nuoren Bonnerin lopputekstijaksossa. Kuva: Kuvakaappaus DVD:Itä.

aukeita maisemia yläkulmasta kuvaavan master shotin ja sinfoniaorkesterin jylhien sävelien saattelemana. Lisäksi kuva-kuvassa-tekniikkaa soveltavissa alkuteksteissä kuullaan Alex Taylorin laulama "Bound to be Back Again", kun Bonner ajaa oletetusti takaisin kotiseuduilleen Arizonaan.

Elokuvamusiikintutkija Anahid Kassabianin (2001) mukaan tietynlaisen musiikkityylin käyttö elokuvassa on liitoksissa käytettyjen musiikillisten keinojen omaksumiin kulttuurisiin merkityksiin. Countrymusiikin valinta elokuvassa viestii tietynlaisia merkityksiä niin miljööstä, henkilöhahmoista kuin identiteeteistä. Alkuteksteissä ei-diegeettisenä kuultava countrytyylinen alkuperäismusiikki itkevine steel-kitaroineen ja pianolirkutteluineen luo vaikutelmaa Etelän ja lounaisosien miljööstä ja cowboy-identiteetistä, missä country on keskeisessä asemassa.

Countrymusiikki tulvii elokuvassa lähdemusiikkina autoradiosta, kapakoiden jukebokseista ja Rod Hartin yhtyeen soittamana kohtauksessa, jossa koko Bonnerien perhe on kapakassa. Kapakkakohtauksessa lähdemusiikki on pääasiassa dialogille alisteinen osa kapakan äänimaisemaa, mikä kohtauksessa luo tunnelmaa ja vaikutelmaa tyypillisestä amerikkalaisesta country-kapakasta. Samassa kohtauksessa kuultava Hartin kitaran, basson ja rumpujen muodostaman yhtyeen esittämä ja countrylaulaja Merle Haggardin ja Bonnie Owensin kirjoittama kappale "Today I Started Loving You Again" (1968) puolestaan kuvastaa nuoren Bonnerin ja ja kilpailevan rodeotähden tyttöystävä Charmainen orastavaa romanssia parin tanssiessa ja mustasukkaisen poikaystävän katsoessa päältä.

Countrytyylinen alkuperäismusiikki toimii myös elokuvassa kuvan toimintaa korostavana elementtinä, esimerkiksi Precossin kaupungin suuria rodeokilpailuja kuvaavassa kohtauksessa. Kilpailut alkavat, kun Yhdysvaltojen lippu nostetaan salkoon isänmaallisuutta korostavan kansallislaulun säestämänä. Hilpeän banjonäppäilyn ja eloisan polkkatyylisen rytmin sävyttämänä countrytyylinen instrumentaalikappale käynnistyy, kun sekuntikello laitetaan päälle lähikuvassa, jolloin ensimmäinen ratsastaja syöksyy ulos aitauksesta. Yhdessä pitkässä otoksessa vauhkoontunut hevonen riepottelee selässään istuvaa cowboyta kuin räsynukkea, kunnes lähiku- 


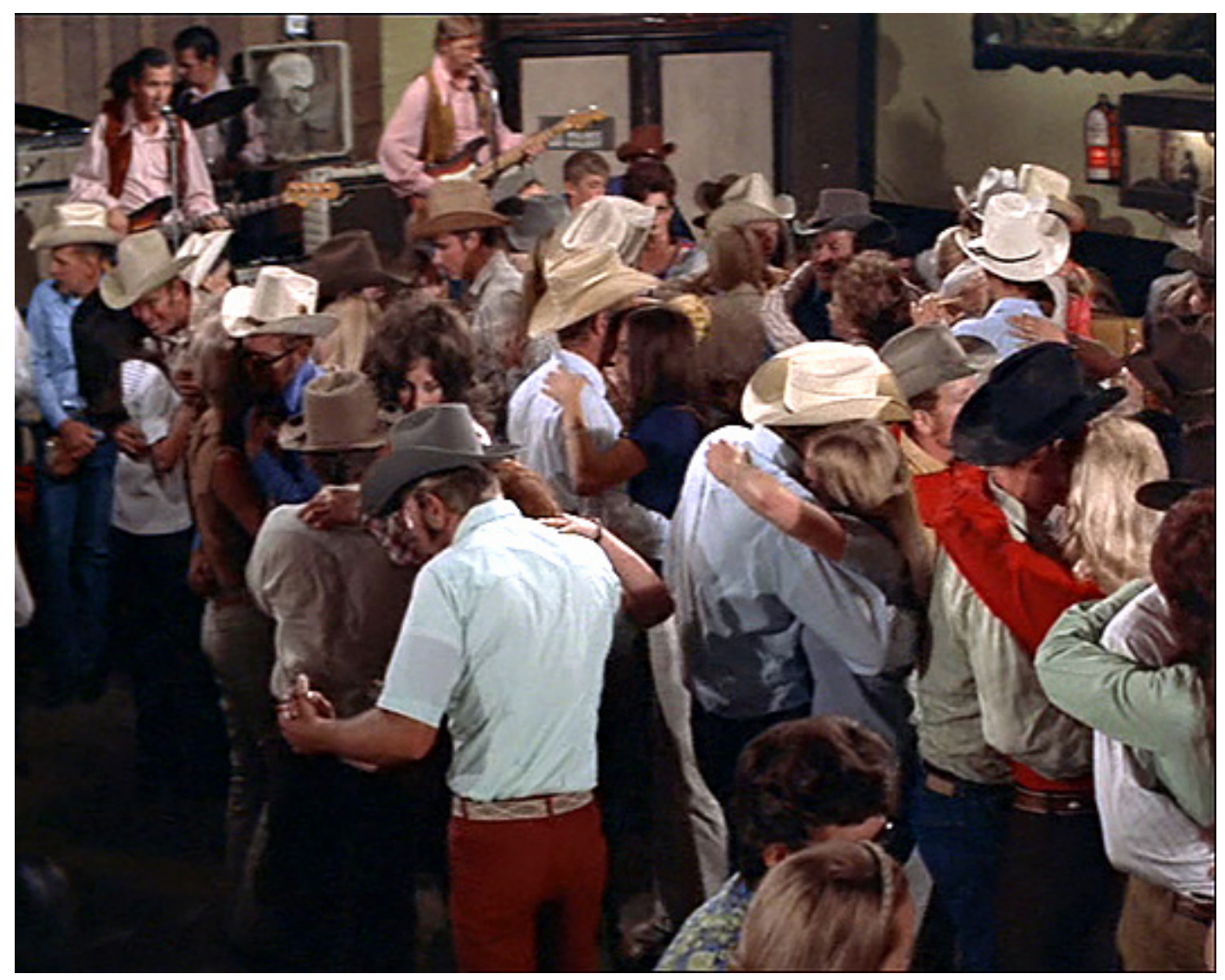

Countrylaulaja Rod Hart yhtyeineen tanssittaa countrykapakkaväkeä. Kuva: Kuvakaappaus DVD:Itä.

vassa nähtävä summeri surisee ajan loppumisen merkiksi. Ratsatusosioiden välissä kuultava summerin ääni katkaisee eloisan countrymusiikin, mikä luo humoristista vaikutelmaa ja ilmentää myös ratsastajan vuoron vaihtumista. Seuraa montaasimaisia nopeita leikkauksia, joissa cowboyt heiluvat hevosen selässä, paikoin Peckinpahille tyypillisten hidastusefektien korostamina. Ratsastusten välissä nähdään katkelma hevosen selästä putoavasta ratsastajasta. Seuraavan ratsastajan jälkeen oletettavasti pudonnutta ratsastajaa laitetaan paareilla ambulanssiin. Rinnakkaiset nopeat katkelmat vaihtelevat nykyhetkessä ja tulevaisuudessa tapahtuneiden asioiden välillä.

Kun Bonner kiipeää aitaukseen odottamaan vuoroaan, musiikki hiljenee, jolloin vaimeahko bassorumpu ja pikkurummun pintoihin "kilkuteltu" steppirytmi luovat kohtaukseen jännitystä. Pikkurummun pärinä saattelee ratsastuksen aloitusta kuin sirkuksen trapetsitaiteilijan uhkarohkeaa hyppyä.

\section{Lähiluku esipuhe-jaksosta}

Nuori Bonner alkaa Peckinpahille ominaisesta, nopeiden lyhyiden leikkausten ja hidastustehosteiden sävyttämästä montaasimaisesta esipuheesta, jossa leikataan ristiin J.R. Bonnerin kilpailusta ja sen jälkeisistä tapahtumista. Kuva häivytään sisään, kun härän selässä ratsastukseen valmistautuvaa Bonneria kuvataan kasvoista. Kun Bonner nyökkää ajanottajalle, nähdään lyhyt lähikuva aitauksen avaavista käsistä ja ajastimen päälle napsauttamisesta. Lyhyestä ajastimen lähikuvasta siirrytään 
hidastettuun katkelmaan raivokkaalla Sunshine-nimisellä härällä ratsastavasta Bonnerista. Hidastuksen aikana yleisö hurraa suosikilleen, ja härän kaulassa oleva lehmänkello kilahtelee reaaliajassa, mikä viittaa ohjaajan usein käyttämään tekniikkaan. Esimerkiksi elokuvan Hurja joukko (The Wild Bunch, USA, 1968) verisessä mutta runollisessa ammuskelufinaalissa näyttävien hidastusten aikana laukaukset ja muut taistelun äänet kuullaan normaaleina. Tämä tuo elokuvaan sekä unenomaista ja runollista vaikutelmaa.

Ratsastuksesta kuva häivytetään ristiin, kun karjan kiinniottamiseen käytettävää köydettä, lassoa kantava Bonner kävelee sisään talliin, jolloin alun rakeinen kuva muuttuu selväksi. Tämä osoittaa leikkausten sijoittuvan eri aikaan. Bonnerin kävellessä kohti kameraa taustalla kuultava kuuluttaja sanoo: "Päivänpaisteelle ei vertaista. Kukaan ei ole vielä läpäissyt kahdeksan sekunnin rajaa." Kuuluttajaäänen voi ajatella kuuluvan joko muistumana aiemmin tapahtuneesta tai samaan aikaan kuultavana diegeettisenä tarinatilan sisäisenä äänenä, mikä ilmoittaa Bonnerin epäonnistuneen tavoitteessaan. Kuulutuksen aikana kuullaan myös korkeasta rekisteristä lirkutteleva piano, mikä on yksi keskeisistä Nashville-countrysoundin perusteista. Tallista siirrytään takaisin rodeoaitaukseen, missä cowboyasusteiset miehet katsovat, kun musta härkä käyskentelee kohti aitausta ammuen ja puskien aitaa sarvillaan.

Letkeä valssirytminen country-tyylinen kappale alkaa nousevasta bassoaiheesta, jolloin kuva siirtyy takaisin talliin, missä Bonner kävelee viistosti kohti kameraa. Kappaleessa rummut soittavat countrylle tyypillistä, pelkistettyä jazz-valssikomppia, kun kitara soittaa pitkiä sointuja, pianon lirkutellessa taustalla kudosta koristelevia kuvioita. Musiikillisen kudoksen taustalla kuultava puhdas Hammond-urkumatto luo kohtaukseen harrasta tunnelmaa. Samalla nähdään pienempi ruutu kuvan vasemmassa alalaidassa, missä Bonner kiipeää aidan yli härän selkään. Kuulutus kertoo myös hänen vuoronsa olevan seuraavaksi. Ruutu suurenee ja valtaa kuvan, jolloin siirrytään takaisin takaumaan. Kuva pysähtyy, kun elokuvan nimi ilmestyy ruudun keskelle. Kuva jakautuu horisontaalisesti kahtia härän selkään nousevan Bonnerin pysäytyskuvasta ja jaloista kuvatusta, tallissa kävelevästä Bonnerista, mistä siirrytään jälleen talliin. Kamera nousee ylös, jolloin seuraa lähikuva Bonnerista. Ennen alhaalta ylöspäin tapahtuvaa pyyhkäisysiirtymää rodeoaitaukseen kuuluttajan taustalla kuullaan härän liikkeestä kilisevää lehmänkelloa, mikä symboloi siirtymistä kahden aikajatkumon välillä. Pyyhkäisyn jälkeen portti aukeaa, ja Bonner ratsastaa Sunshinen (suom. "Päivänpaiste") selässä ulos.

Kuva pysähtyy yllättäen, minkä jälkeen Ida Lupinon nimen sisältävästä ruudusta siirrytään takaisin talliin, missä lähikuvassa nähtävä Bonner avaa sinisen puseronsa paljastaen rintansa. Kuva pyyhkäisee oikealta vasemmalle kilpailuun, jakaen kuvan kahteen ruutuun: Vasemmassa hidastetussa ruudussa Bonner yrittää pitää itsepintaisesti kiinni satulan tapista, vaikka peli on käytännössä menetetty, kun taas oikeanpuoleisessa ruudussa yläosaton Bonner tutkii isoa mustelmaa oikeassa kyljessään. Pellepukuiset "rodeopellet" yrittävät ottaa härän kiinni, mutta turhaan. Pysäytyskuvien aikana mennyttä aikaa kuvaavan ruudun ääniraita hiljenee, mikä osoittaa siirtymistä toiseen aikaan ja tilaan. Kun seesteinen itkevä steel-kitara aloittaa soolonsa, takaisin häivyttyy hetken aikaa pimennossa ollut oikea ruutu, jossa Bonner laittaa sidettä lantionsa ympärille. Vasemmanpuoleisen ruudun kuva pysähtyy, ja pyyhkäistään oikealta vasemmalle. Sidettä ympärilleen kiertävästä Bonnerista siirrytään aitaukseen, missä Sunshine heittelee satulatapista roikkuvaa Bonneria kuin perunasäkkiä. Välissä nähdään katkelma tallissa, jossa ohi kävelevä cowboyhattuihin mies tokaisee hämmästyksen merkiksi: "Oohwie". Sanonta on tyypillinen cowboyden "hihkaisu", mikä kuvastaa erikoista, innokasta tilannetta. "Hihkuva" cowboy luo ironista vaikutelmaa, koska Bonner on epäonnistunut katkerasti yrityksessään päihittää voittamaton härkä, "Päivänpaiste". 


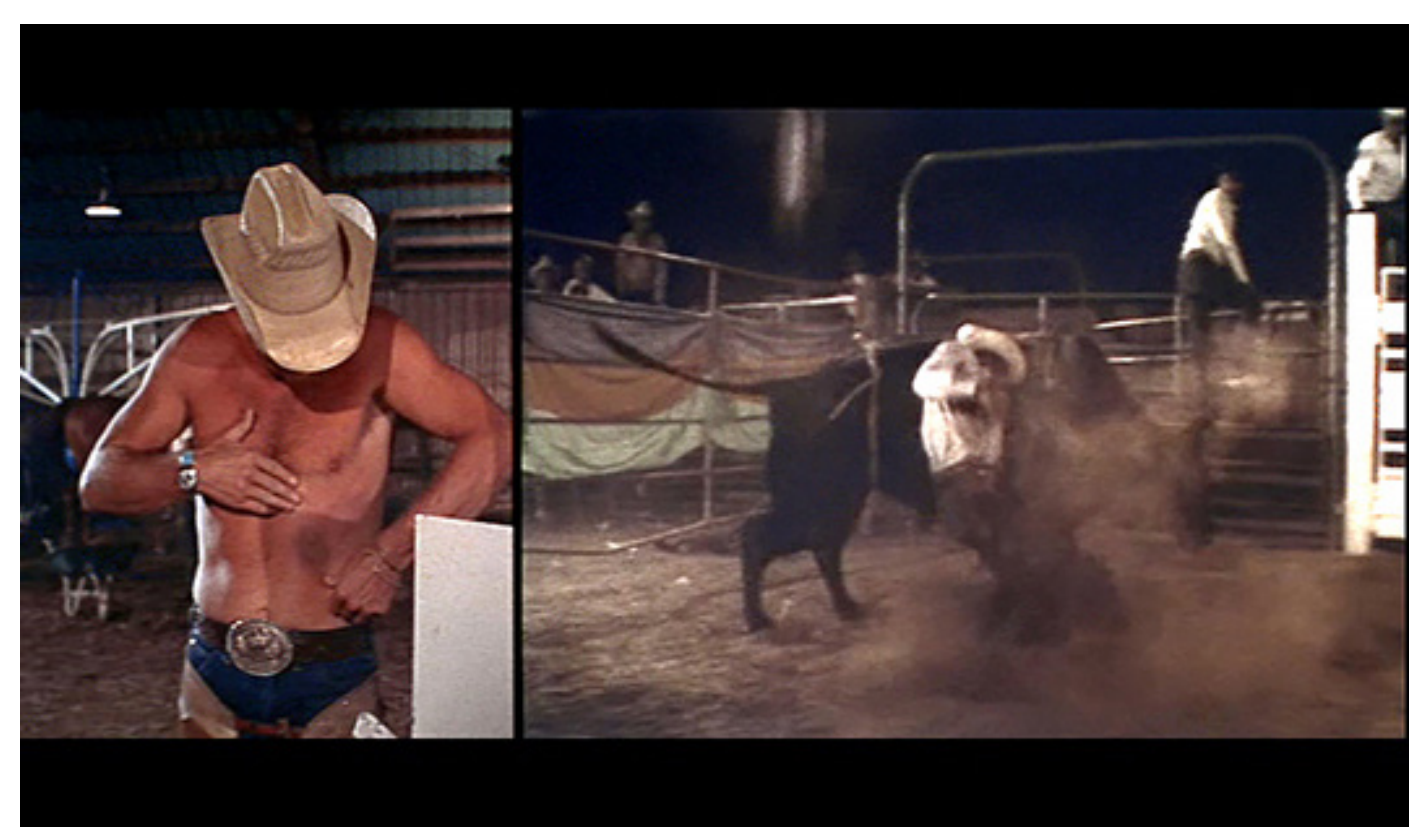

Bonner tutkii vammojaan elokuvan esipuhemontaasissa. Kuva: Kuvakaappaus DVD:Itä.

Seuraa lyhyt katkelma rodeoaitauksesta, mistä siirrytään nykyisyyteen, kun kuvan oikeaan alalaitaan ilmestyvä pieni ruutu laajenee koko kuvan laajuudelle. Tällöin Bonner istuu hevosenkuljetusperäkärrynsä jalansijan päällä ja irrottaa kannuksia cowboy-saappaistaan. Kohtauksen lopuksi, kun rummut soittavat pikkurumpuun tasaisia neljäsosia ja sähkökitara ja basso näppäilevät melodista kuviota, Bonner tokaisee tutulleen: "Ehkä minun pitäisi harkita alan vaihtoa." Tuttu suhisee vastaukseksi ja lisää: "Nähdään Prescottissa J. R." Kommentti ikään kuin vihjaa, ettei Bonner usko itsekään alanvaihtoon. Seesteinen country-tyylinen teema päättyy tahdin ensimmäiselle iskulle, toisen pisteelliselle ja kolmannelle iskulle potkivan bassorumpurytmin tukeman kitaramelodian ja korkeasta rekisteristä näppäilevään bassokitaran liu'utteleviin korukuvioihin, kun Bonner hakee hevosensa tallin aitauksesta ja ohjaa sen peräkärryynsä.

Elokuvan esipuhekohtauksessa country-tyylinen elokuvateema luo vaikutelmaa cowboy-identiteetistä ja modernista Lännen miljööstä. Hidastempoisille countryvalsseille, kuten "I'm So Lonesome I Could Cry", "He'1l Have to Go" ja "El Paso" tyypillinen jazz-valssirytmi luo kohtaukseen rauhallista ja seesteistä tunnelmaa, mikä toimii kontrapunktina kuvan tapahtumiin, jossa rodeoratsastaja Bonner on juuri pudonnut härän selästä. Kontrapunkti tarkoittaa tässä yhteydessä prosessia, jossa musiikki luo ristiriidan kautta kuvalle uuden merkityksen (Välimäki 2008, 44).

\section{Yhteenvetoa Nuoren Bonnerin audiovisuaalisuudesta}

Countrymusiikkia on käytetty paljon erilaisissa elokuvissa enenevissä määrin 1960-luvulta asti, jolloin Tennesseen kaupungissa muodostunut pop-tyylinen Nashville-soundi kukoisti. Countryn käytöllä halutaan tavallisesti luoda vaikutelmaa Etelävaltioiden ja lounaisosien miljööstä ja valkoisesta identiteetistä, mihin country tyypillisesti assosioituu. Musiikkisemiotiikasta sovelletut, Etelään ja länteen sijoittuvissa elokuvissa käytetyt elokuvamusiikilliset vakioaiheet, joita kutsun countrytopoksiksi, kytkeytyvät niiden toistuvan käytön vuoksi laajempaan kulttuuriseen kontekstiin. 
Merkityksenannossa keskeistä on kärjistävää representaatiota ja kahtia jakamista soveltava stereotyypittely, mikä on tarjonnut elokuvissa aineksia niin komediaan kuin kauhuun. Countrymusiikkia leimaavat myös sen yleiset negatiiviset stereotyypit, kuten konservatiivisuus ja muutosvastarinta, mutta myös isänmaallisuus ja maanläheisyys. Ei ole tosin tärkeää, millaisia Etelän maaseudun asukkaat todellisuudessa ovat, vaan miten heidät esitetään populaarikulttuurissa.

Sam Peckinpahin ohjaamassa elokuvassa Nuori Bonner countrymusiikki ja sen erilaisten tyylien viitteet ovat keskeinen osa niin musiikkiraitaa kuin myös merkityksenantoa. Elokuvassa countrya kuullaan tyylitopoksina Jerry Fieldingin säveltämässä, bändisoittimia sisältävässä orkestraalisessa alkuperäismusiikissa, jossa countrylle tyy pilliset instrumentit luovat vaikutelmaa Yhdysvaltojen lounaisosien miljööstä ja alueeseen stereotyyppisesti yhdistettävästä cowboy-identiteetistä. Elokuvasta löytyy myös countrytyylin harmoniarakenteita ja tyyliviitteitä muistuttavia sävellyksiä, joita voidaan kutsua tyyppitopoksiksi. Lisäksi autenttista vaikutelmaa miljööstä luo lähdemusiikkina baareissa jukeboksista ja bändin soittamana sekä autoradiosta soivat countrykappaleet, kuten "Rodeo Man" ja "Today I Started Loving You Again", jotka vievät katsojan konkreettisesti Arizonan pikkukaupungin countrykapakkaan. Countrymusiikki on siis keskeinen osa regionaalisen identiteetin ilmentämistä, mikä johtuu niiden toistuvasta viljelystä populaarikulttuurissa.

\section{Elokuvat}

Bonnie ja Clyde (Bonnie and Clyde). USA 1967, ohj. Arthur Penn.

Dukes of Hazzard. USA, CBS 1979-1985.

Hurja joukko (The Wild Bunch). USA 1968, ohj. Sam Peckinpah.

Konna ja Koukku (Smokey and the Bandit). USA 1977, ohj. Hal Needman.

Kumi sulaa asfaltilla (Bad Georgia Road). USA 1977, ohj. John C. Broderick.

Nuori Bonner (Junior Bonner). USA 1972, ohj. Sam Peckinpah.

"Papan ihmelääke" ("Granpa vs. the Sexual Inadequacy"). USA, Fox 1994. Simpsonit (The Simpsons). USA, Fox 1989-

Two Thousand Maniacs. USA 1964, ohj. Herchell Gordon Lewis.

Valkea Salama (White Lightning). USA 1973, ohj. John Sargent.

Veijarit (The Reivers). USA 1969, ohj. Mark Ridell.

\section{Lähteet}

Hall, Stuart (2002) Identiteetti. Suom. ja toim. Mikko Lehtonen ja Juha Herkman. Tampere: TammerPaino Oy.

Hautsalo, Liisamaija (2010) Kehtolaulutopos neljässä suomalaisessa oopperassa. Etnomusikologian vuosikirja vol 22. Suomen etnomusikologinen seura.

Kassabian, Anahid (2001) Hearing Film: Tracking Identifications in Contemporary Hollywood Film. New York and London: Routledge.

Malone, Bill C. (1975) Country Music U.S.A.: A Fifty-Year History. Austin \& London: The University of Texas Press.

Monelle Raymond (2006) The Musical Topic: Hunt, Military and Pastoral. Bloomington and Indianapolis: Indiana Unoiversity Press.

Ratner, Leonard (1980) Classic Music: Expression, Form and Style. New York: Schimmer Books.

Välimäki, Susanna (2008) Miten sota soi? Sotaelokuva, musiikki ja ääni. Tampere: Tampere University Press. 